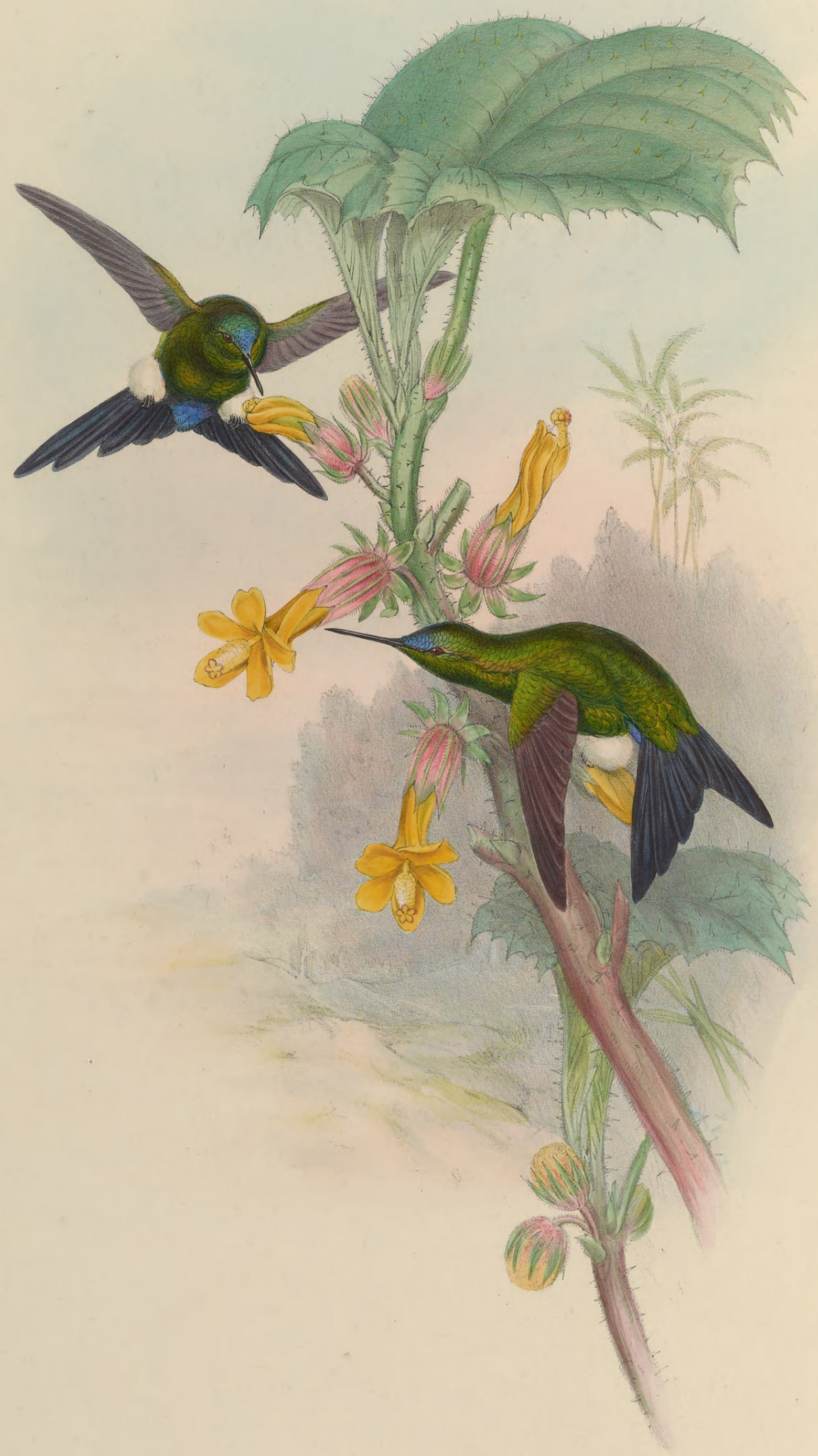




\section{ERIOCNEMIS LUCIANI.}

\section{Buquet's Puff-leg.}

Trochilus Luciani, Bourc. Ann. Sci. et Phys. de Lyon, 1847, p. 624.

Hylocharis Luciani, Gray and Mitch. Gen. of Birds, vol. i. p. 114, Hylocharis, sp. 4.

Eriopus huciani, Bonap. Consp. Gen. Av., p. 80, Eriopus, sp. 4.

T. (Eriopus) luciani, Jard. Cont. to Orn., 1850, p. 2.

THIs species was originally characterized by M. Bourcier in 1847 , from a single specimen procured by M. De Lattre near the village of Guaca in the Republic of Ecuador. Since that period the bird has become tolerably common in our collections, many specimens having been obtained by M. Bourcier during his late sojourn in that country. For the examples contained in Sir William Jardine's collection and in my own, we are indebted to Professor Jameson of Quito, who states that the bird is very common on the western side of Pichincha, at an elevation of from ten to twelve thousand feet.

The sexes of E. Luciani, like those of E. Mosquera and E. cupreiventris, are so similar as scarcely to be distinguished by their colouring; both have the white ruffs, but as usual these ornaments are less developed in the female. The young birds of the first year may be distinguished by the green hue of the throat being entirely absent, that part being clothed by feathers of a nearly uniform blackish brown, without any metallic brilliancy; as the bird advances in age, a line of luminous green feathers extends down the middle of the throat. On the forehead of some adults a brilliant bluish green mark is found, while in others it is totally absent: probably this difference is due to the more or less approach to maturity.

M. Bourcier has named this species Luciani, in honour of M. Lucien Buquet, one of the most distinguished entomologists of France.

Forehead shining bluish green; crown of the head, upper surface, upper and under wing-coverts bronzy green, passing into shining green on the upper tail-coverts; wings purplish brown; tail purplish black; al the under surface lustrous golden green; under tail-coverts rich blue; thigh-ruffs snow-white; bill black; feet brown.

The figures represent the two sexes of the size of life. 


\section{$2 \mathrm{BHL}$ Biodiversity Heritage Library}

Gould, John. 1860. "Eriocnemis luciani, Buquet's Puff-leg. [PI. 273]." A monograph of the Trochilida, or family of humming-birds 4, https://doi.org/10.5962/p.317082.

View This Item Online: https://www.biodiversitylibrary.org/item/108334

DOI: https://doi.org/10.5962/p.317082

Permalink: https://www.biodiversitylibrary.org/partpdf/317082

\section{Holding Institution}

Smithsonian Libraries

\section{Sponsored by}

Smithsonian Institution Libraries

\section{Copyright \& Reuse}

Copyright Status: NOT_IN_COPYRIGHT

This document was created from content at the Biodiversity Heritage Library, the world's largest open access digital library for biodiversity literature and archives. Visit BHL at https://www.biodiversitylibrary.org. 